Prepared in cooperation with the Missouri Department of Conservation

Concentration of Elements in Hellbender Blood and Fish Fillets from the 2006 Missouri Department of Conservation Monitoring Programs

Open-File Report 07-1229 



\section{Concentration of Elements in Hellbender Blood and Fish Fillets from the 2006 Missouri Department of Conservation Monitoring Programs}

By Thomas W. May, Michael J. Walther, William G. Brumbaugh, Jeffrey T.

Briggler ${ }^{1}$, Yue-wern Huang ${ }^{2}$, and Michael J. McKee ${ }^{1}$

${ }^{1}$ Missouri Department of Conservatiom

${ }^{2}$ University of Missouri-Rolla

Prepared in cooperation with the Missouri Department of Conservation

Open-File Report 2007-1229 


\section{U.S. Department of the Interior DIRK KEMPTHORNE, Secretary}

\section{U.S. Geological Survey \\ Mark D. Myers, Director}

\section{U.S. Geological Survey, Reston, Virginia: 2007}

For product and ordering information:

World Wide Web: http://www.usgs.gov/pubprod

Telephone: 1-888-ASK-USGS

For more information on the USGS--the Federal source for science about the Earth, its natural and living resources, natural hazards, and the environment:

World Wide Web: http://www.usgs.gov

Telephone: 1-888-ASK-USGS

Any use of trade, product, or firm names is for descriptive purposes only and does not imply endorsement by the U.S. Government.

Although this report is in the public domain, permission must be secured from the individual copyright owners to reproduce any copyrighted materials contained within this report.

Suggested citation:

May, T.W., Walther, M.J., Brumbaugh, W.G., Briggler, J.T., Huang, Yue-wern, and McKee, M.J., 2007, Concentrations of elements in hellbender blood and fish fillets from the 2006 Missouri Department of Conservation monitoring programs: U.S. Geological Survey Open-File Report 2007-1229, 18 p. 


\section{Contents}

Abstract
Introduction
Sampling History
Methods
Ouality Control
Results
Quality Control Results
References Cited
Tables

\section{Tables}

1. Dry weight concentrations of calcium, cadmium, mercury, and lead and lead/ calcium molar ratios in Missouri Department of Conservation 2006 General Contaminant Monitoring fish fillets.

2. Wet weight concentrations of calcium, cadmium, mercury, and lead in Missouri Department of Conservation 2006 General Contaminant Monitoring fish fillets

3. Dry weight concentrations of calcium, zinc, cadmium, mercury, and lead and lead/calcium molar ratios in Missouri Department of Conservation 2006 Resource Assessment and Monitoring fish fillets

4. Wet weight concentrations of calcium, zinc, cadmium, mercury, and lead in Missouri Department of Conservation 2006 Resource Assessment and Monitoring fish fillets

5. Concentrations of chromium, cobalt, cadmium, mercury, and lead in Missouri Department of Conservation 2006 Hellbender Monitoring Program hellbender blood 


\section{Conversion Factors and Datum}

\begin{tabular}{|c|c|c|}
\hline Multiply & By & To obtain \\
\hline \multicolumn{3}{|c|}{ Length } \\
\hline millimeter) & 0.03937 & inch (in.) \\
\hline micrometer $(\mu \mathrm{m})$ & 0.0000393 & inch (in.) \\
\hline \multicolumn{3}{|c|}{ Volume } \\
\hline liter (L) & 33.82 & ounce, fluid (fl. oz) \\
\hline milliliter (mL) & 0.034 & ounce, fluid (fl. oz) \\
\hline \multicolumn{3}{|c|}{ Mass } \\
\hline $\operatorname{gram}(\mathrm{g})$ & 0.03527 & ounce, avoirdupois (oz) \\
\hline milligram (mg) & 0.000035 & ounce (oz) \\
\hline
\end{tabular}

Temperature in degrees Celsius $\left({ }^{\circ} \mathrm{C}\right)$ may be converted to degrees Fahrenheit $\left({ }^{\circ} \mathrm{F}\right)$ as follows:

$$
{ }^{\circ} \mathrm{F}=\left(1.8 \times{ }^{\circ} \mathrm{C}\right)+32
$$

Concentrations of chemical constituents in water are given in milligrams per liter (mg/L).

Concentrations of chemical constituents in solid materials are given in micrograms per gram $(\mu \mathrm{g} / \mathrm{g})$. 


\title{
Concentrations of Elements in Hellbender Blood and Fish Fillets from the Missouri Department of Conservation Monitoring Programs
}

\author{
By Thomas W. May, Michael J. Walther, and William G. Brumbaugh, Jeffrey T. Briggler ${ }^{1}$, Yue-wern Huang ${ }^{2}$, \\ and Michael J. McKee ${ }^{1}$
}

\section{Abstract}

This report presents the results of contaminant monitoring surveys conducted annually by the Missouri Department of Conservation to examine the levels of selected elemental contaminants in hellbender (Cryptobranchus alleganiensis) blood and fish. Catfish (Ictalurus furcatus, Ictalurus punctatus, Pylodictis olivaris), redhorse (Moxostoma anisorum, Moxostoma erythrurum), bass (Micropterus salmoides, Micropterus punctulatus, Micropterus lacepède Ambloplites rupestris), walleye (Sander vitreus), and sunfish (Lepomis megalotis) were collected from 17 sites as part of the Department's General Contaminant Monitoring Program. Bluegill (Lepomis macrochirus) and other sunfish (Lepomis megalotis, Lepomis cyanellus) were collected from 18 sites as part of the Department's Resource Assessment and Monitoring Program. Blood from hellbenders was collected from seven sites as part of the Department's Hellbender Monitoring Program.

\section{Introduction}

The Missouri Department of Conservation (MDC) initiated long-term statewide fish monitoring programs in 1984. The programs' designs are to annually select predator and bottom dwelling species from each of 20-30 lakes and streams across Missouri to characterize concentrations of targeted metal and other chemical contaminants. Actual sites monitored each year vary based on data needs, budgets, and personnel resources. Emphasis is on human health and, therefore, incorporates fish fillets, composite samples, and sample replication at each site. In 2006, 17 sites were selected for sampling as part of the MDC General Contaminant Monitoring (GCM) Program. Predator and bottom dwelling species were selected based on the need for specific mercury information (walleye, Sander vitreus; flathead catfish, Pylodictis olivaris; various

${ }^{1}$ Missouri Department of Conservation.

${ }^{2}$ University of Missouri-Rolla. bass species, Micropterus salmoides, Micropterus punctulatus, Micropterus lacepède, Ambloplites rupestris), having a propensity to accumulate lead $(\mathrm{Pb})$, or the potentially greater risk for consumption (large river catfish, Ictalurus Furcatus, Ictalurus Punctatus, Pylodictis Olivaris). In addition to the GCM samples, blood samples were collected from hellbenders (Cryptobranchus alleganiensis) from seven sites in the Missouri Ozarks as part of the MDC Resource Science Division's Hellbender Monitoring Program (HMP). Finally, bluegill (Lepomis macrochirus) and other sunfish (Lepomis megalotis, Lepomis cyanellus) were collected from 18 small wadeable stream sites as part of the MDC Resource Assessment and Monitoring Program (RAM), which consisted of fillets from three fish collected at each site. MDC has requested the assistance of the USGS Columbia Environmental Research Center (CERC) for this monitoring program because of CERC's past experience with aquatic biota monitoring projects and expertise in the preparation and analysis of fish for elemental contaminants. For more detailed information on the overall study design or specific sample information, please contact Jeff $\mathrm{T}$. Briggler (Hellbenders) or Mike McKee (other MDC samples) at the Missouri Department of Conservation.

\section{Sampling History}

A shipment of 90 fish fillet composites was received by CERC's Inorganic Section on November 17, 2006. The samples included skin-on and skinless fillets, depending upon species. Upon receipt, the shipment was assigned CERC batch \#1316 and sample identifications (IDs) 38400-38489. A second shipment of 52 skinless fish fillets, 3 fillets per site, was received on November 17, 2006, and assigned CERC batch \#1317 and sample IDs 38490-38541. A third shipment consisting of 56 samples of hellbender blood was received on November 17, 2006. These samples were assigned CERC batch \#1318 and sample IDs 38542-38597. All samples had been stored since collection at the MDC's Resource Science Center in Columbia, Mo. and were delivered by MDC personnel. Requested analyses included cadmium (Cd), mercury 
$(\mathrm{Hg})$, and lead $(\mathrm{Pb})$ for the GCM samples (shipment 1), zinc ( $\mathrm{Zn}), \mathrm{Cd}$, and $\mathrm{Pb}$ for the RAM samples (shipment 2), and cobalt $(\mathrm{Co})$, chromium $(\mathrm{Cr}), \mathrm{Cd}, \mathrm{Hg}$, and $\mathrm{Pb}$ for the $\mathrm{HMP}$ samples (shipment 3). Because fish fillet samples were highly variable in the way they were extracted and, thus, may have varying amounts of calcium-rich bone fragments that can be comparatively high in $\mathrm{Pb}$, calcium $(\mathrm{Ca})$ was added to the list of requested elements as a potential means to help explain $\mathrm{Pb}$ variability (Schmitt and Finger, 1987).

\section{Methods}

\section{Homogenization and Lyophilization}

GCM fillet samples were chopped with a titanium meat cleaver on a cleaned polypropylene cutting board. Larger fillets were ground with a Hobart ${ }^{\circledast}$ meat grinder, whereas, smaller fillets were ground in a modified KitchenAid ${ }^{\circledR}$ meat grinder. The smallest mass samples were simply minced with a ceramic knife. All chopped and ground samples then were lyophilized followed by either hand kneading in a plastic (polyethylene) bag or crushing with a rolling pin in a plastic bag. All dried and ground products were stored at room temperature in a 40-milliliter $(\mathrm{mL})$ glass vial in a desiccator.

RAM samples were received in the form of single fillets per sample. Each sample was minced with a ceramic knife. An aliquot of the minced material less than $(<) 30$ grams (g) was lyophilized to a constant dry weight using a Genesis ${ }^{\circledast} 35 \mathrm{EL}$ lyophilizer; percent moisture was determined in conjunction with the lyophilization process. After drying, fillet samples were reduced to a coarse powder by crushing with a glass rod. All dried and ground products were stored at room temperature in a 40-mL glass vial in a desiccator.

\section{Chemical Preparation}

To prepare fish samples for $\mathrm{Ca}, \mathrm{Zn}, \mathrm{Cd}$, and $\mathrm{Pb}$ analysis, a dried sample (about or approximately $0.25 \mathrm{~g}$ ) was heated with 6-mL nitric acid in a sealed low-pressure Teflon ${ }^{\circledR}$ vessel in a laboratory microwave oven. The cooled digestate liquid was transferred into a $125-\mathrm{mL}$ polyethylene bottle with ultrapure water [greater than ( $>$ ) $10 \mathrm{megOhms}$ per centimeter (megOhm/ $\mathrm{cm})$ ] and diluted to a final weight of $101.5 \mathrm{~g}$. Final acid matrix was 6 percent nitric acid. For the determination of $\mathrm{Hg}$ in fish samples, there was no chemical preparation (digestion) because the dried sample was decomposed thermally during instrumental analysis (see below). The lyophilized hellbender blood samples were digested for analysis by quantitative inductively coupled plasma-mass spectrometry (ICP-MS). A 20- to 50-milligram (mg) subsample of each hellbender blood sample was weighed into a 10-mL Teflon ${ }^{\circledR}$-lined, screw-cap borosilicate test tube and $0.5 \mathrm{~mL}$ sub-boiled nitric acid was added. After a 1-hour pre-digestion at room temperature, the tube was sealed and placed in a hot-block heater at 110 degrees Celsius for 30 minutes. The tube was cooled for 10 minutes, $0.2 \mathrm{~mL}$ high-purity hydrogen peroxide was added, and the tube was returned to the hot-block heater for $30 \mathrm{~min}-$ utes. After cooling, the sample was diluted to a final volume of $5 \mathrm{~mL}$. Final acid matrix was 10 percent nitric acid.

\section{Instrumental Analysis}

Calcium, $\mathrm{Cr}, \mathrm{Co}, \mathrm{Zn}, \mathrm{Cd}$, and $\mathrm{Pb}$ analyses were conducted using a PE/SCIEX Elan $6000^{\circledR}$ ICP-MS, which was set up in "Standard Mode" and optimized according to the manufacturer's specifications. Samples were automatically delivered to the ICP-MS by means of a software-controlled CETAC ASD-500 autosampler/autodiluter system. All sample digestates were analyzed with a ten-fold (10X) predilution by autodiluter.

The ICP-MS quantitative method was designed to determine the following masses: ${ }^{44} \mathrm{Ca}$ and ${ }^{48} \mathrm{Ca},{ }^{52} \mathrm{Cr}$ and ${ }^{53} \mathrm{Cr}$, ${ }^{59} \mathrm{Co},{ }^{66} \mathrm{Zn}$ and ${ }^{68} \mathrm{Zn},{ }^{111} \mathrm{Cd}$ and ${ }^{114} \mathrm{Cd}$, and $\mathrm{Pb}$ as the sum of three masses $\left({ }^{206} \mathrm{~Pb}+{ }^{207} \mathrm{~Pb}+{ }^{208} \mathrm{~Pb}\right)$. The internal standards were $\mathrm{Sc}$ at 10 nanograms per milliliter $(\mathrm{ng} / \mathrm{mL}), \mathrm{Rh}(10 \mathrm{ng} / \mathrm{mL})$, and $\mathrm{Bi}(10 \mathrm{ng} / \mathrm{mL})$, which were metered into the sample line via peristaltic pump. Calibration standards for analyses were as follows: $\mathrm{Ca}-2,500,5,000$, and $10,000 \mathrm{ng} / \mathrm{mL} ; \mathrm{Co}, \mathrm{Cr}$, and $\mathrm{Pb}-5,10,20,40 \mathrm{ng} / \mathrm{mL} ; \mathrm{Cd}-1.5,3.0,6.0,12 \mathrm{ng} / \mathrm{mL}$; $\mathrm{Zn}-75,150,300 \mathrm{ng} / \mathrm{mL}$. During the actual analysis, any digestate concentration greater than the upper calibration standard for any element was automatically diluted 10 times in a serial fashion until its concentration was below this level. Where multiple masses for an element were measured, the concentration reported was based on the mass exhibiting least interferences, which were as follows: ${ }^{44} \mathrm{Ca},{ }^{53} \mathrm{Cr},{ }^{66} \mathrm{Zn},{ }^{114} \mathrm{Cd}$ (five instances) and ${ }^{111} \mathrm{Cd}$ (one instance), and $\mathrm{Pb}$ as the sum of three masses ${ }^{206} \mathrm{~Pb}+{ }^{207} \mathrm{~Pb}+{ }^{208} \mathrm{~Pb}$ ).

Mercury was determined with a Milestone DMA- 80 analyzer equipped with an automated sample carousel. With this method, a dried fish sample (40-60 mg) was combusted in a stream of oxygen. All $\mathrm{Hg}$ in the sample was volatilized and trapped by amalgamation on a gold substrate and was thermally desorbed and quantitated by atomic absorption spectrophotometry (United States Environmental Protection Agency, 1998).

\section{Quality Control}

The samples were digested and analyzed in seven groups or batches for $\mathrm{Ca}, \mathrm{Cd}$, and $\mathrm{Pb}$, and eight batches for $\mathrm{Hg}$. The quality control incorporated in the digestion stage of the samples (for subsequent ICP-MS analysis) included digestion blanks, reference materials, replicates, and spikes. For the determination of $\mathrm{Ca}, \mathrm{Co}, \mathrm{Cr}, \mathrm{Zn}, \mathrm{Cd}$, and $\mathrm{Pb}$ by ICPMS, instrumental quality control included calibration checks, laboratory control solutions, duplicate digestate analysis, 
analysis spikes, and interference checks (dilution percent difference and a synthetic interference solution). Quality control for $\mathrm{Hg}$ included blanks, independent calibration verification checks, replicates, pre-combustion spikes, and tissue reference materials. All quality control results were tabulated to provide an overview of quality assurance and to facilitate interpretation.

\section{Results}

Percent moisture, concentrations in micrograms per gram $(\mu \mathrm{g} / \mathrm{g})$ dry weight of $\mathrm{Ca}, \mathrm{Cd}, \mathrm{Hg}$, and $\mathrm{Pb}$, and molar ratios of $[\mathrm{Pb} / \mathrm{Ca}]\left(1 \mathrm{X} 10^{-6}\right)$ for the GCM samples are presented in table 1 . To facilitate comparison with any regulatory guidelines, concentrations of $\mathrm{Ca}, \mathrm{Cd}, \mathrm{Hg}$ and $\mathrm{Pb}$ are presented in $\mu \mathrm{g} / \mathrm{g}$ wet weight in table 2. Similarly, percent moisture, concentrations ( $\mu \mathrm{g} / \mathrm{g}$ dry weight) of $\mathrm{Ca}, \mathrm{Zn}, \mathrm{Cd}$, $\mathrm{Hg}$, and $\mathrm{Pb}$, and molar ratios of $[\mathrm{Pb} / \mathrm{Ca}]\left(1 \mathrm{X} 10^{-6}\right)$ for the RAM samples are presented in table 3 , and wet weight concentrations are presented in table 4 . Percent moisture and concentrations ( $\mu \mathrm{g} / \mathrm{g}$ dry weight) of $\mathrm{Cr}, \mathrm{Co}, \mathrm{Cd}, \mathrm{Hg}$, and $\mathrm{Pb}$ in hellbender blood from the HMP are presented in table 5. For this report all sample and quality control data are discussed in terms of the dry weight results only.

GCM: Calcium concentrations were variable among fillet samples, but within each species differences were generally within a factor of 2 (table 1). Such variation was presumably because of differing bone content in the fillets and was undoubtedly influenced by significant variations in fillet preparation techniques as well as by the fish species (such as catostomids, or sucker fish, possess numerous tiny intermuscular bones). Fillets from some species contained noticeably higher Ca concentrations than other, for example, longear sunfish compared to walleye. Although $\mathrm{Ca}$ is normally not a target analyte, fillet $\mathrm{Ca}$ concentrations are useful when target analytes include those that markedly accumulate in bone, for example, $\mathrm{Pb}$. Thus, measurements of $\mathrm{Ca}$ can serve to help explain variability of $\mathrm{Pb}$ concentrations for individual samples caused by the inclusion of variable amounts of Ca-rich tissue in the sample [1]. Cadmium concentrations ( $\mu \mathrm{g} / \mathrm{g}$ dry weight) were less than 0.050 in most samples, with many samples having concentrations less than method quantitation and method detection limits. Two of the highest $\mathrm{Cd}$ concentrations were from a flathead catfish sample (\#38439; $0.092 \mu \mathrm{g} / \mathrm{g}$ dry weight) and a longear sunfish sample (\#38463; $0.28 \mu \mathrm{g} / \mathrm{g}$ dry weight). On an individual fish basis, the highest mercury concentrations were measured in six largemouth bass, nine walleye, and six catfish; these ranged from 1.59 to $5.57 \mu \mathrm{g} / \mathrm{g}$ dry weight. All walleye and largemouth bass samples, and six catfish samples equaled or exceeded the current United States Environmental Protection Agency (USEPA) fish consumption advisory for $\mathrm{Hg}$ of $0.30 \mu \mathrm{g} / \mathrm{g}$ wet weight (United States Environmental Protection Agency, 2001). All catfish fillet samples except one exhibited $\mathrm{Pb}$ concentrations less than or equal to $(\leq) 0.10$ $\mu \mathrm{g} / \mathrm{g}$ dry weight. The one exception was sample 38407 (site 297), which had a Pb concentration of $0.51 \mu \mathrm{g} / \mathrm{g}$ dry weight. This sample did not contain an unusually high concentration of $\mathrm{Ca}$, indicating that the fillet $\mathrm{Pb}$ concentration was not influenced by inclusion of bone fragments (table 1). Numerous fillets from redhorse and golden redhorse species exceeded $0.10 \mu \mathrm{g} / \mathrm{g}$ dry weight, ranging from 0.11 to $0.42 \mu \mathrm{g} / \mathrm{g}$ dry weight. The highest $\mathrm{Pb}$ concentrations were observed in fillets of longear sunfish, which ranged from 0.30 to $1.23 \mu \mathrm{g} / \mathrm{g}$ dry weight. Notably, these fish also had the highest Ca concentrations, suggesting that bone fragments may have been present in the fillets, which in addition to probable $\mathrm{Pb}$ exposure, might explain these comparably higher $\mathrm{Pb}$ concentrations.

RAM: Calcium concentrations in sunfish were highly variable, ranging from 357 to $4,490 \mu \mathrm{g} / \mathrm{g}$ dry weight (table 3 ). Within the green sunfish species, Ca concentrations varied as much as eightfold, whereas longear sunfish exhibited $\mathrm{Ca}$ variations as much as sevenfold. Zinc concentrations were fairly uniform across the sample set, with variation of less than threefold among fillet samples. Zinc concentrations ranged from 20.9 to $54.3 \mu \mathrm{g} / \mathrm{g}$ dry weight. Cadmium concentrations ranged from less than 0.008 to $0.43 \mu \mathrm{g} / \mathrm{g}$ dry weight. All Cd concentrations were below $0.10 \mu \mathrm{g} / \mathrm{g}$ dry weight except for three samples (38539, $0.41 \mu \mathrm{g} / \mathrm{g}$ dry weight; 38490, $0.43 \mu \mathrm{g} / \mathrm{g}$ dry weight; $38528,0.17 \mu \mathrm{g} / \mathrm{g}$ dry weight). Mercury concentrations in bluegill and other sunfish ranged from 0.050 to $0.90 \mu \mathrm{g} / \mathrm{g}$ dry weight. All $\mathrm{Hg}$ concentrations were less than the current USEPA fish consumption advisory for $\mathrm{Hg}$ of $0.30 \mu \mathrm{g} / \mathrm{g}$ wet weight (USEPA, 2001). Pb concentrations in bluegill and sunfish fillets ranged from $<0.003$ to $0.21 \mu \mathrm{g} / \mathrm{g}$ dry weight. All samples had $\mathrm{Pb}$ concentrations $<0.10 \mu \mathrm{g} / \mathrm{g}$ dry weight except for two samples (38499, $0.21 \mu \mathrm{g} / \mathrm{g}$ dry weight; 38501, 0.10 $\mu \mathrm{g} / \mathrm{g}$ dry weight).

HMP: Chromium concentrations in hellbender blood ranged from $<0.13$ to $6.87 \mu \mathrm{g} / \mathrm{g}$ dry weight (table 5). Some of the highest $\mathrm{Cr}$ concentrations were from the following samples: $38573,6.87 \mu \mathrm{g} / \mathrm{g}$ dry weight; 38575, $2.17 \mu \mathrm{g} / \mathrm{g}$ dry weight; $38582,2.52 \mu \mathrm{g} / \mathrm{g}$ dry weight. Cobalt concentrations in hellbender blood ranged from 0.12 to $1.41 \mu \mathrm{g} / \mathrm{g}$ dry weight. Some of the higher Co concentrations were from samples 38546 ( $1.41 \mu \mathrm{g} / \mathrm{g}$ dry weight) and $38550(1.37 \mu \mathrm{g} / \mathrm{g}$ dry weight). Cadmium concentrations in hellbender blood ranged from $<0.002$ to $0.11 \mu \mathrm{g} / \mathrm{g}$ dry weight. All except one Cd concentration $(38573,0.11 \mu \mathrm{g} / \mathrm{g}$ dry weight) were $<0.06 \mu \mathrm{g} / \mathrm{g}$ dry weight. Mercury concentrations ranged from 0.080 to 0.65 $\mu \mathrm{g} / \mathrm{g}$ dry weight, and $\mathrm{Pb}$ concentrations ranged from 0.013 to $0.23 \mu \mathrm{g} / \mathrm{g}$ dry weight.

\section{Quality Control Results}

Calibration Verification: A calibration blank and an independent calibration verification standard (ICVS) were analyzed every 10 samples to confirm the calibration status of the ICP-MS during instrumental analyses of the fish fillet and 
diet digestates for $\mathrm{Ca}, \mathrm{Cr}, \mathrm{Co}, \mathrm{Zn}, \mathrm{Cd}$, and $\mathrm{Pb}$; blanks were within plus and minus $( \pm)$ three times the instrument detection limits for each element and ICVS recoveries were within the target of 90 to 110 percent of the ICVS standard concentration for each element. Three reference solutions (Spex Claritas Instrument Check Standard ICS-1;National Institute of Standards and Technology (NIST) Standard Reference Material (SRM) 1640: Trace Elements in Natural Water; High Purity Standards Certified Reference Solution Trace Metals in Fish: HP CRM-TF) used as laboratory control samples exhibited elemental recoveries ranging from 93 to 104 percent. Calibration verification reference tissues (National Research Council Canada (NRCC) SRM DOLT-2; International Atomic Energy Agency (IAEA) SRM 407-Trace Elements and Methylmercury in Fish Tissue; NRCC SRM DOLT-3: Dogfish Liver) for total $\mathrm{Hg}$ were analyzed at the beginning and end of the instrumental runs to confirm the calibration status of the DMA- 80 system; percent errors were within the target of \pm 10 percent except for three cases where percent errors were 12.0, 10.3, and 10.5.

Reference Materials: Recoveries of $\mathrm{Ca}, \mathrm{Zn}, \mathrm{Cd}$ and $\mathrm{Pb}$ in three tissue reference materials (NIST SRM 1566b: Oyster Tissue, $\mathrm{n}=5$; IAEA SRM 407, $\mathrm{n}=5$; NRCC SRM DORM-2: Dogfish Muscle, $n=5$ ) ranged from 83 to 108 percent, with one higher recovery for $\mathrm{Pb}$ (164 percent), and averaged 99 percent. Recoveries of $\mathrm{Cr}, \mathrm{Co}, \mathrm{Cd}$, and $\mathrm{Pb}$ in two blood reference materials (SeroNorm 201705: Trace Elements in Whole Blood, $\mathrm{n}=1$; ClinChek 8841 Whole Blood, Control Level II, $\mathrm{n}=1$ ) ranged from 100 to 141 percent and averaged 119 percent. Recoveries of $\mathrm{Hg}$ from eight different tissue reference materials (NIST SRM 966: Bovine Blood, $\mathrm{n}=2$; SeroNorm 201705, $\mathrm{n}=2$; ClinChek 8841, $\mathrm{n}=2$; IAEA 407, $\mathrm{n}=8$; NIST RM50: Albacore Tuna, $\mathrm{n}=5$; NRCC DOLT-3, $\mathrm{n}=8$; NRCC DORM-2, $\mathrm{n}=6$; NIST SRM 2976: Mussel Tissue, $\mathrm{n}=6$ ) ranged from 98 to 107 percent and averaged 101 percent.

Method and Instrumental Precision: Method precision from the triplicate digestion and analysis of fish fillet $(n=8)$ and blood (SeroNorm 201705, n=1) had percent relative standard deviations (\%RSDs) for $\mathrm{Cr}, \mathrm{Co}, \mathrm{Zn}, \mathrm{Cd}$, and $\mathrm{Pb}$ that were $<37$, except for $\mathrm{Pb}$, which had one higher RSD of 42 percent. This degree of variability for $\mathrm{Pb}$ is not unusual for tissues containing low $\mathrm{Pb}$ concentrations. The RSDs for $\mathrm{Ca}$ were highly variable, apparently because of variability in bone content in the fillets; these ranged from 0.8 to 131 percent. The RSDs for $\mathrm{Hg}(\mathrm{n}=8)$ were all $\leq 4$ percent. Method precision from the duplicate analysis of blood (ClinCheck 8841, $\mathrm{n}=1$ ) and fish fillets $(n=1)$, measured as relative percent difference (RPD), ranged from 5.4 to 36 percent, with higher RPDs for Cd (64 percent, blood) and $\mathrm{Pb}$ (47 percent, fish). Instrumental precision measured as RPD from the analysis of fish fillet $(n=13)$ and blood $(\mathrm{n}=4)$ duplicate digestates was $<10$ percent.

Spikes: Spike recoveries of $\mathrm{Cr}, \mathrm{Co}, \mathrm{Cd}$, and $\mathrm{Pb}$ from reference blood materials $(n=4)$ ranged from 96 to 122 percent and averaged 103 percent. Recoveries of $\mathrm{Ca}, \mathrm{Zn}, \mathrm{Cd}$, and $\mathrm{Pb}$ spiked into fish tissue $(\mathrm{n}=16)$ ranged from 79 to 112 percent and averaged 99 percent. Recoveries of methylmercury hydroxide spiked into fillet tissue $(n=16)$ ranged from 84 to 117 percent.
Post-digestion or analysis spikes for $\mathrm{Cr}, \mathrm{Co}, \mathrm{Cd}$, and $\mathrm{Pb}$ in hellbender blood $(n=6)$ had recoveries ranging from 96 to 113 percent. Recoveries of analysis spikes of $\mathrm{Ca}, \mathrm{Zn}, \mathrm{Cd}$, and $\mathrm{Pb}$ from fish fillet digestates $(\mathrm{n}=13)$ ranged from 97 to 109 percent.

Interference Checks: As a check for potential interferences, dilution percent differences (DPDs) based on fivefold dilutions of the blood $(n=4)$ and fish fillet $(n=14)$ digestates were determined. DPDs were $\leq 10$ percent for all elements except $\mathrm{Ca}$. Calcium had DPDs ranging from 12 to 23 percent, indicating the potential of a small interferent for this element. A synthetic solution containing high concentrations of aluminum, $\mathrm{Ca}$, iron, magnesium, sodium, phosphorus, potassium, sulfur, carbon, molybdenum, and titanium was analyzed to observe the effects of these potential interfering elements on the determination of $\mathrm{Cd}$ and $\mathrm{Pb}$ concentrations in this matrix. Recoveries were within the \pm 20 percent target except for one instance for $\mathrm{Cr}$ (138 percent) and three instances for $\mathrm{Cd}$ (134 percent, 138 percent, and 129 percent). Cadmium exceeded this target because of an interference from molybdenum (Mo) oxide $\left({ }^{98} \mathrm{Mo}^{16} \mathrm{O}\right)$ on ${ }^{114} \mathrm{Cd}$ caused by the high Mo concentration in this synthetic matrix. Such a high Mo concentration is not a probable concern for the hellbender blood or fish fillet matrix.

Blank Equivalent Concentrations (BEC): BECs $(\mathrm{Ca}, \mathrm{Cr}$, $\mathrm{Co}, \mathrm{Zn}, \mathrm{Cd}, \mathrm{Pb}$ ) for digestion blanks prepared with each batch were determined; all BECs were less than the corresponding method detection limits (MDLs) except for one instance of $\mathrm{Zn}(0.68$ BEC vs $0.27 \mu \mathrm{g} / \mathrm{g}$ MDL) and three instances of $\mathrm{Pb}$ (0.012 BEC vs $0.011 \mu \mathrm{g} / \mathrm{g}$ MDL; 0.010 BEC vs $0.007 \mu \mathrm{g} / \mathrm{g}$ MDL; $0.007 \mathrm{BEC}$ vs 0.003). All BECs for $\mathrm{Hg}$ were less than the corresponding Hg MDLs.

Instrument Detection, Method Detection, and Method Quantitation Limits: Instrument detection limit (IDL) for $\mathrm{Hg}$ was 0.003 nanograms (ng); the IDLs for other target analytes in nanograms per milliliter were as follows: $\mathrm{Cr}, 0.020$; $\mathrm{Co}$, $0.001 ; \mathrm{Ca}, 2.49$; Zn, 1.78; Cd, 0.002; Pb, 0.002. Method detection limits (MDL) were computed in micrograms per gram dry weight for each batch of samples as:

$$
3 \mathrm{X}\left(\mathrm{SD}_{\mathrm{b}}^{2}+\mathrm{SD}_{\mathrm{S}}^{2}\right)^{1 / 2}
$$

where

and

$\mathrm{SD}_{\mathrm{b}} \quad=$ standard deviation of a blank $(\mathrm{n}=3)$;

$\mathrm{SD}_{\mathrm{S}} \quad=$ standard deviation of a low level sample or spiked sample $(\mathrm{n}=3)$; and were as follows:

Cr, 0.13; Co, 0.005; Ca, 3.40 to 11.4 ; Zn, 0.27 and 0.54; $\mathrm{Cd}, 0.002$ to $0.014 ; \mathrm{Hg}, 0.002$ to $0.017 ; \mathrm{Pb}, 0.003$ to 0.018 . Method quantitation limits (MQLs) were calculated in micrograms per gram dry weight as $3.3 \mathrm{x}$ MDLs and were as follows: $\mathrm{Cr}, 0.43$; $\mathrm{Co}, 0.017$; $\mathrm{Ca}, 11.2$ to 37.6 ; $\mathrm{Zn}, 0.89$ and 1.78; $\mathrm{Cd}, 0.007$ to $0.046 ; \mathrm{Hg}, 0.008$ to $0.056 ; \mathrm{Pb}, 0.010$ to 0.059 . All quality control results for the study were within acceptable limits as specified by USGS-CERC. 


\section{References Cited}

Schmitt, C.J., and Finger, S.E., 1987, The effects of sample preparation on measured concentrations of eight elements in edible tissues of fish from streams contaminated by lead mining: Archives of Environmental Contamination and Toxicology, v. 16, p.185-207.

United States Environmental Protection Agency, 1998, Mercury in solids and solutions by thermal decomposition, amalgamation, and atomic absorption spectrophotometry: accessed August 28, 2007, at http://www.epa.gov/epaoswer hazwaste/test/up4a.htm\#7_series.

United States Environmental Protection Agency, 2001, Water quality criterion for protection of human health: methylmercury: United States Environmental Protection Agency, EPA-823-R-01-001, January 2001, Office of Water, Washington, D.C., 16 p. 

Tables 


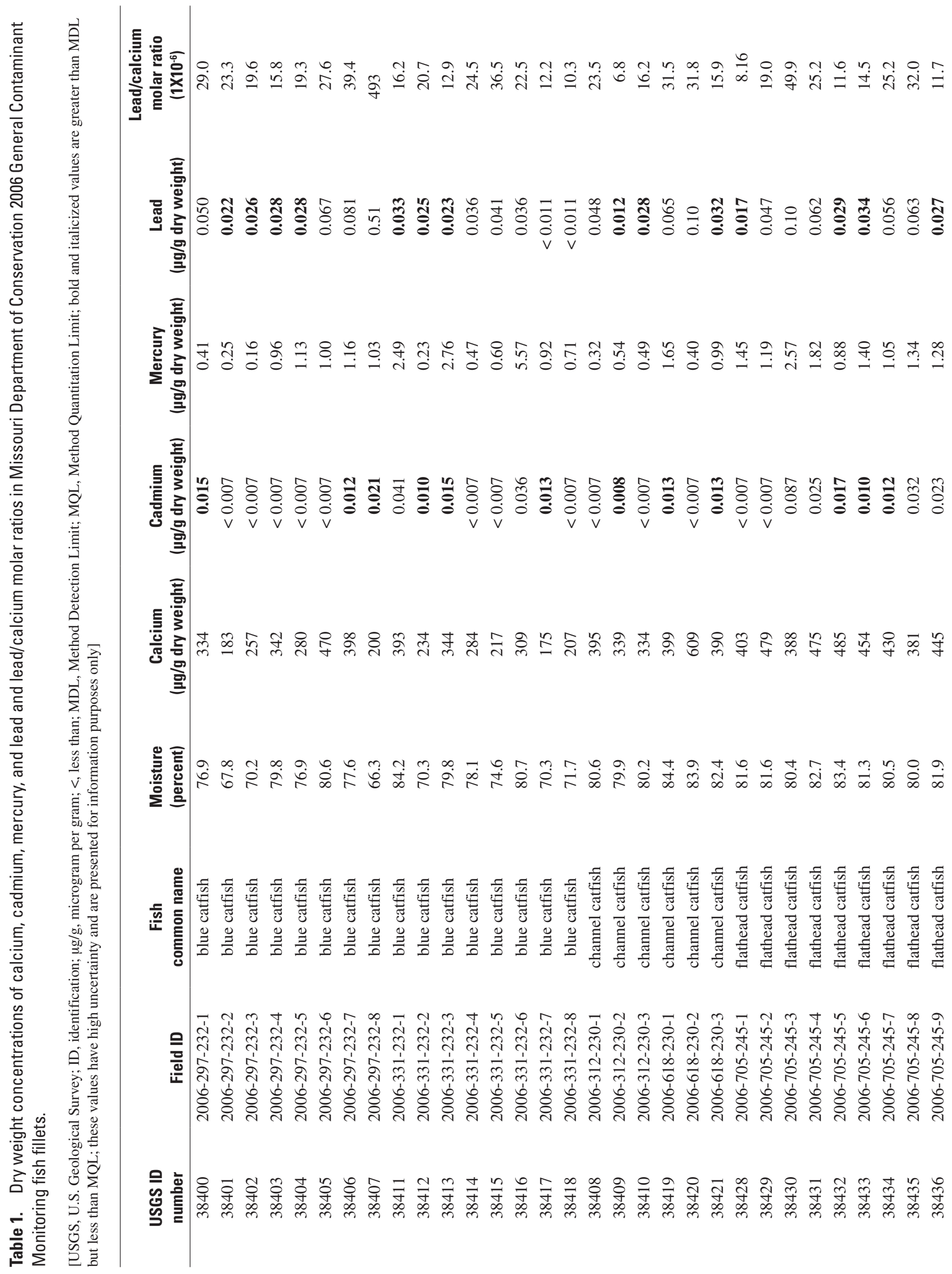




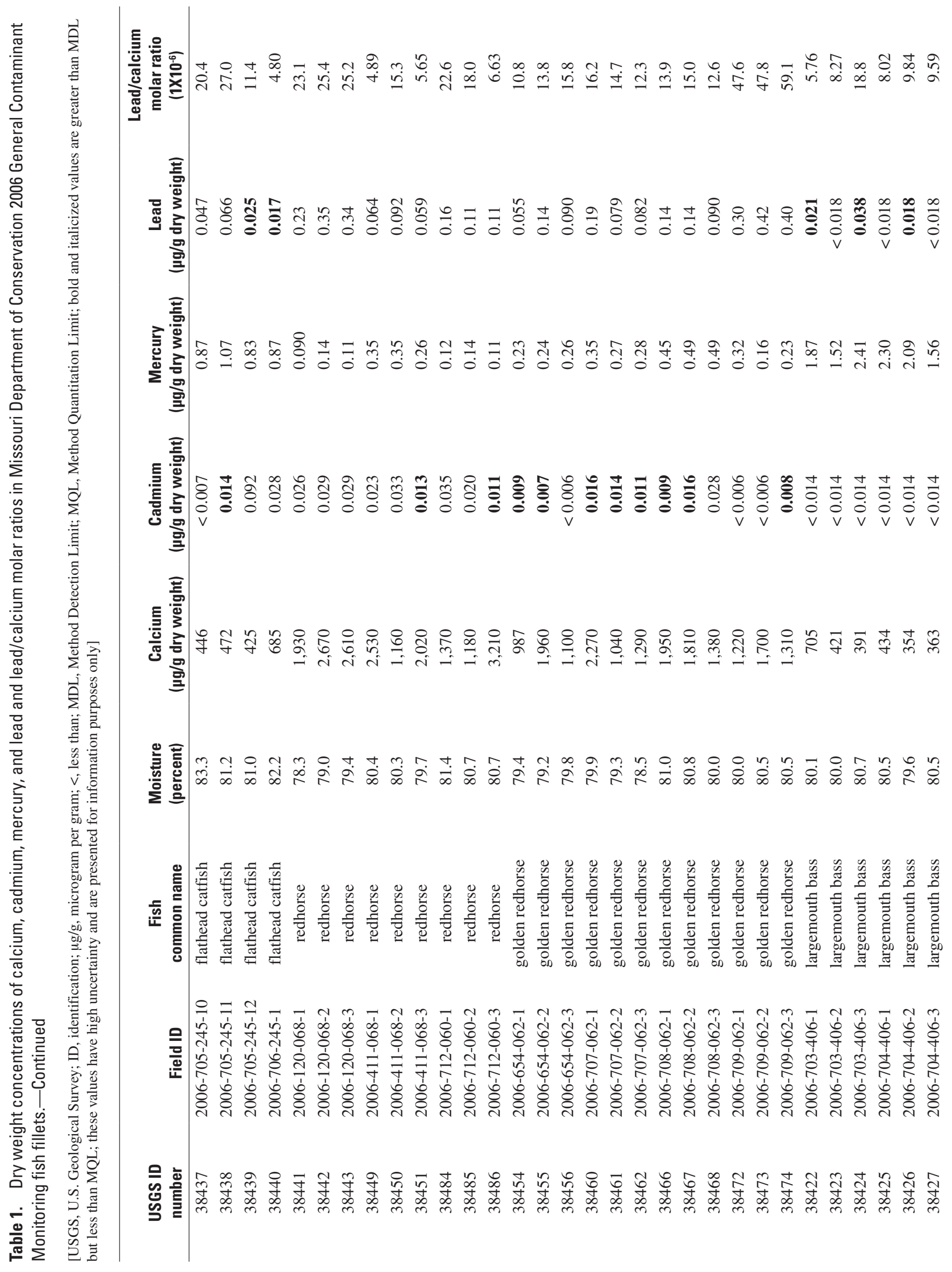




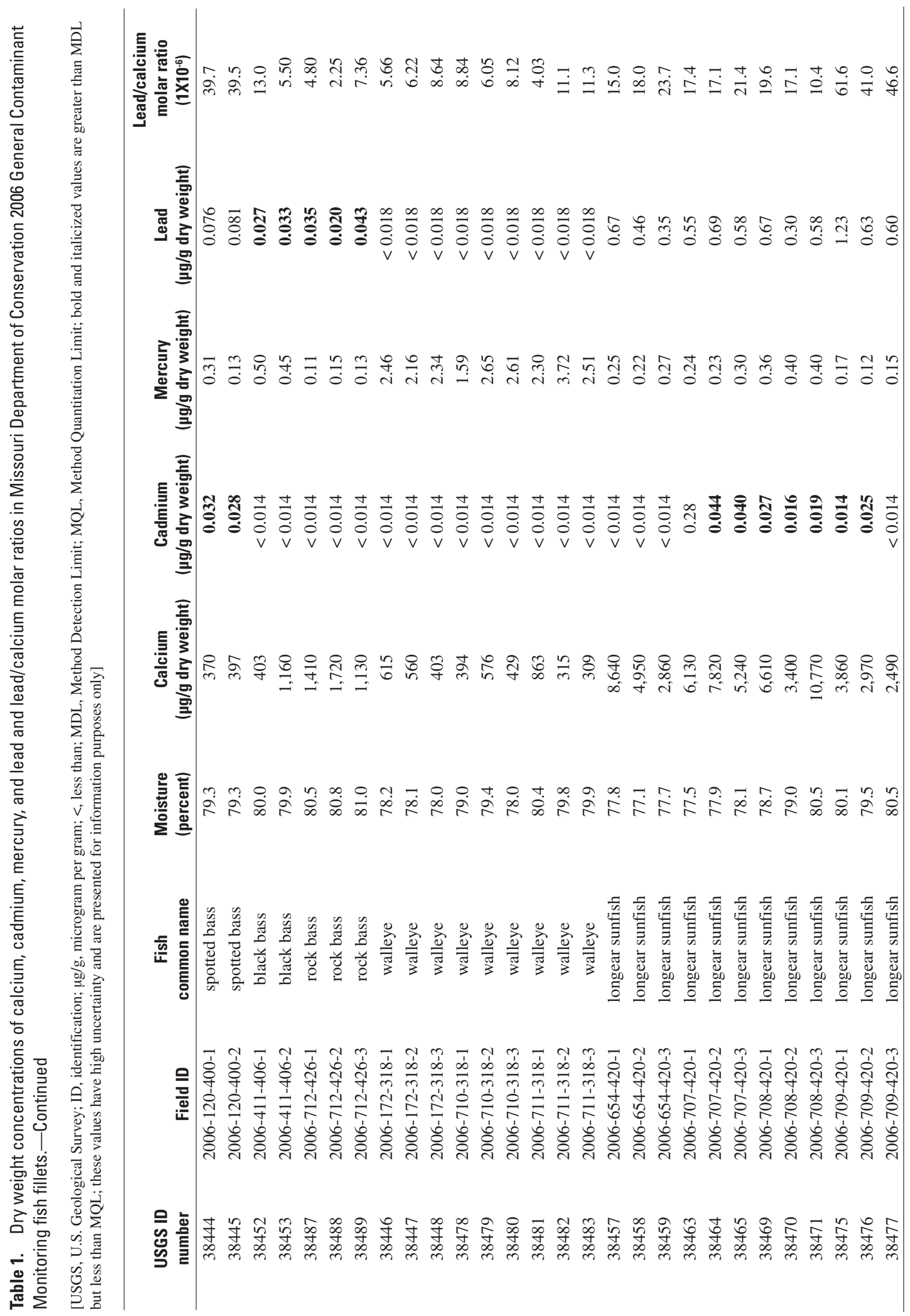


Table 2. Wet weight concentrations of calcium, cadmium, mercury, and lead in Missouri Department of Conservation 2006 General Contaminant Monitoring fish fillets.

[USGS, U.S. Geological Survey; ID, identification; $\mu \mathrm{g} / \mathrm{g}$, microgram per gram; <, less than; MDL, Method Detection Limit; MQL, Method Quantitation Limit; bold and italicized values are greater than MDL but less than MQL; these values have high uncertainty and are presented for information purposes only]

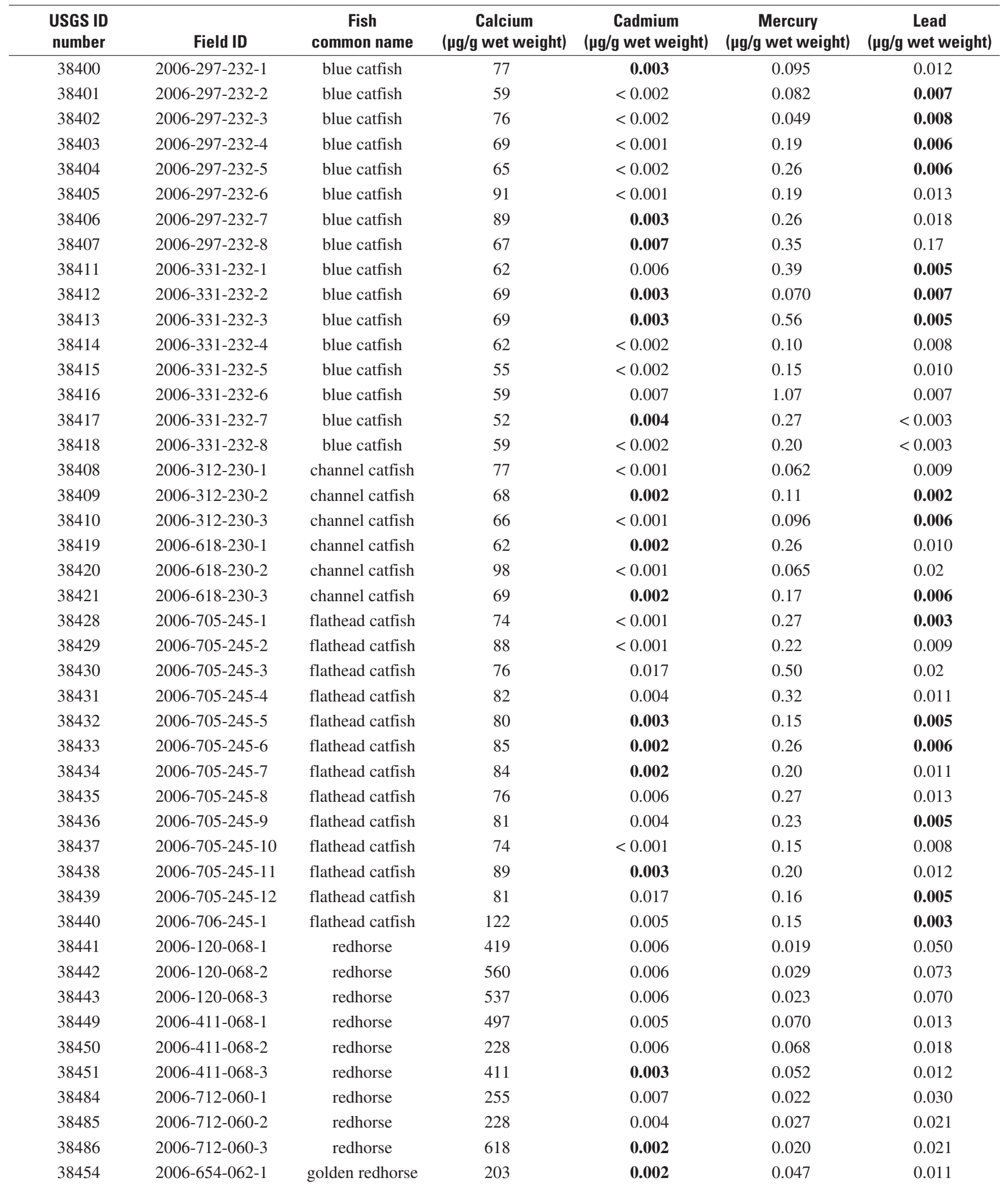


Table 2. Wet weight concentrations of calcium, cadmium, mercury, and lead in Missouri Department of Conservation 2006 General Contaminant Monitoring fish fillets.-Continued

[USGS, U.S. Geological Survey; ID, identification; $\mu \mathrm{g} / \mathrm{g}$, microgram per gram; <, less than; MDL, Method Detection Limit; MQL, Method Quantitation Limit; bold and italicized values are greater than MDL but less than MQL; these values have high uncertainty and are presented for information purposes only]

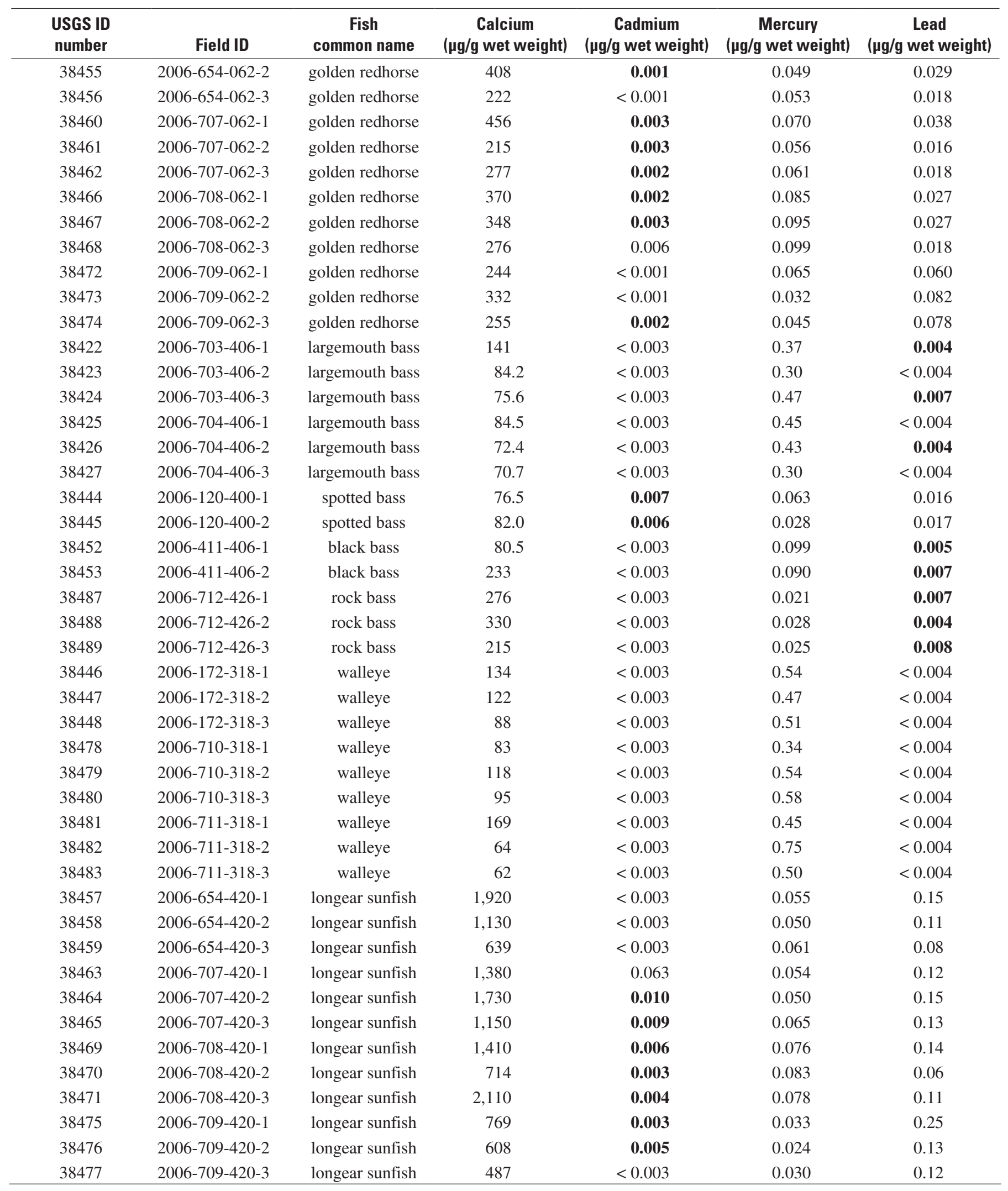




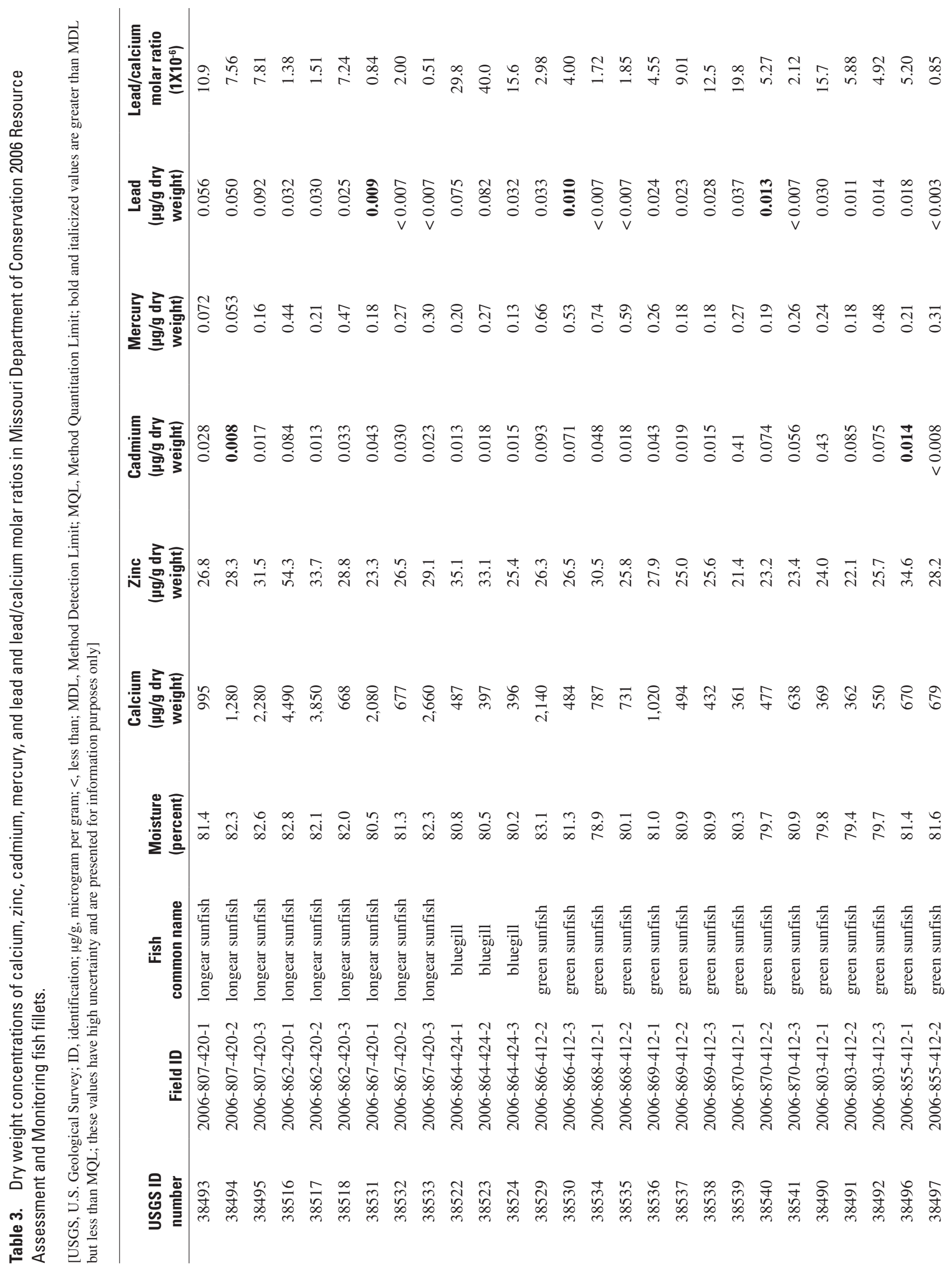




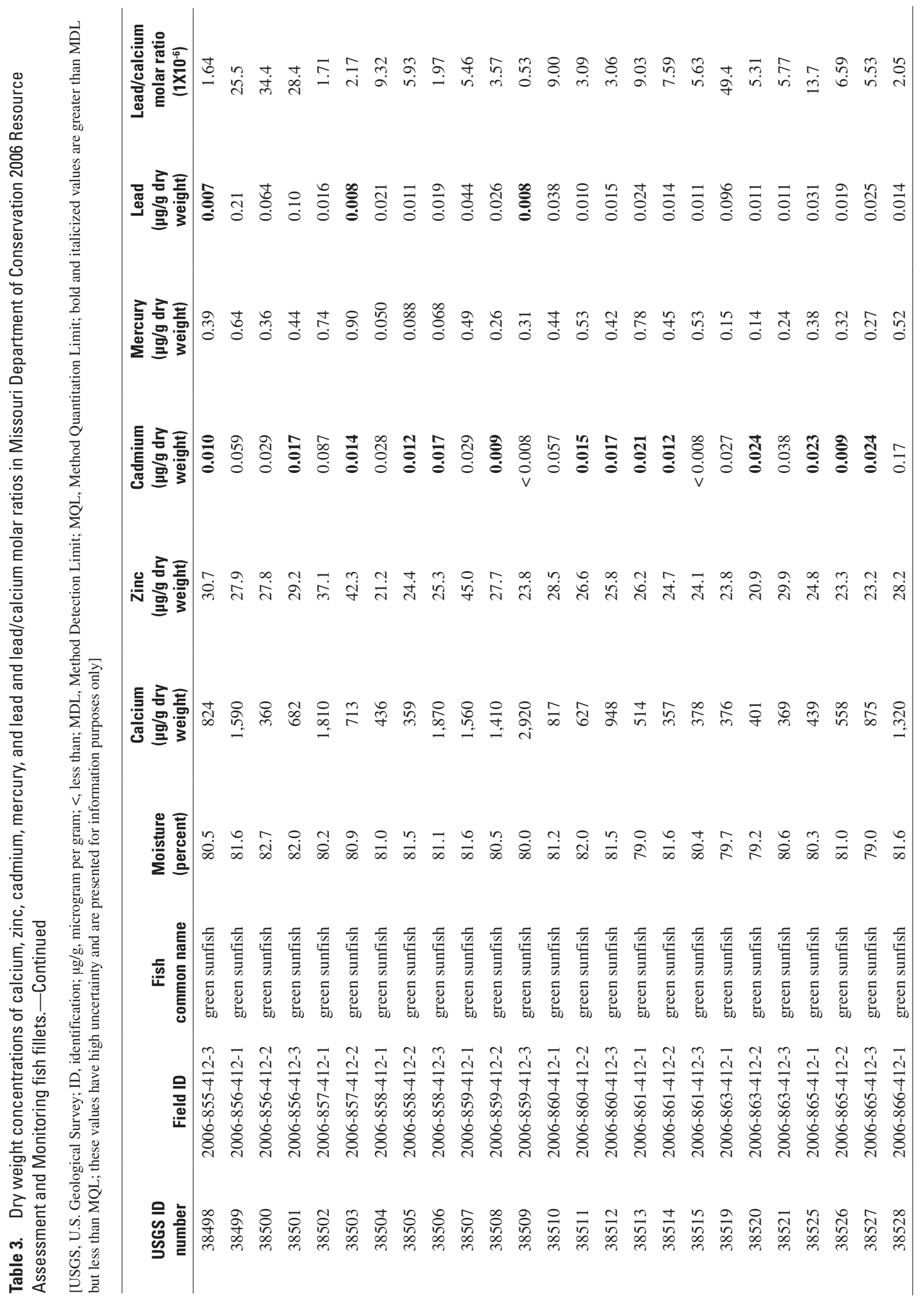




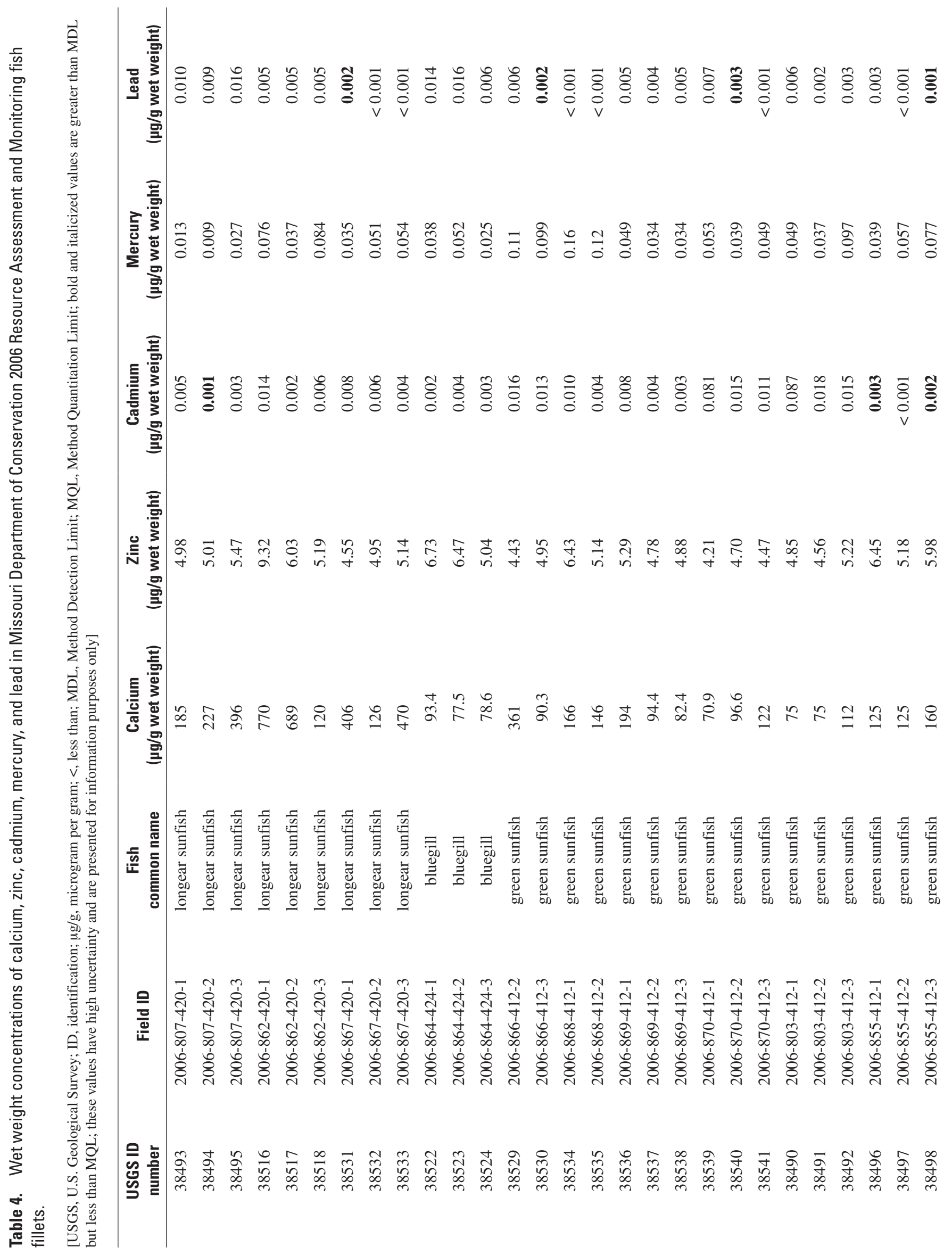




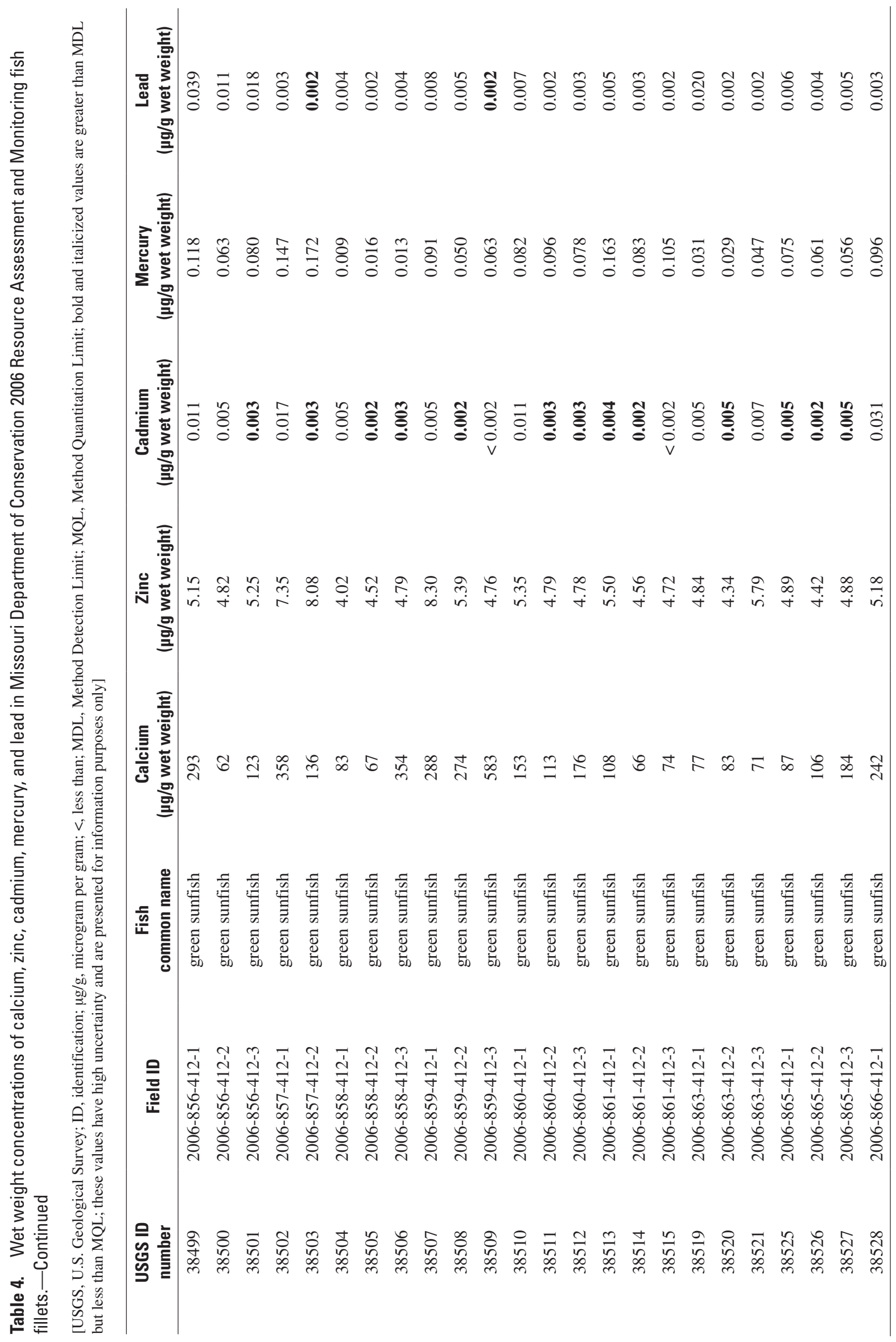




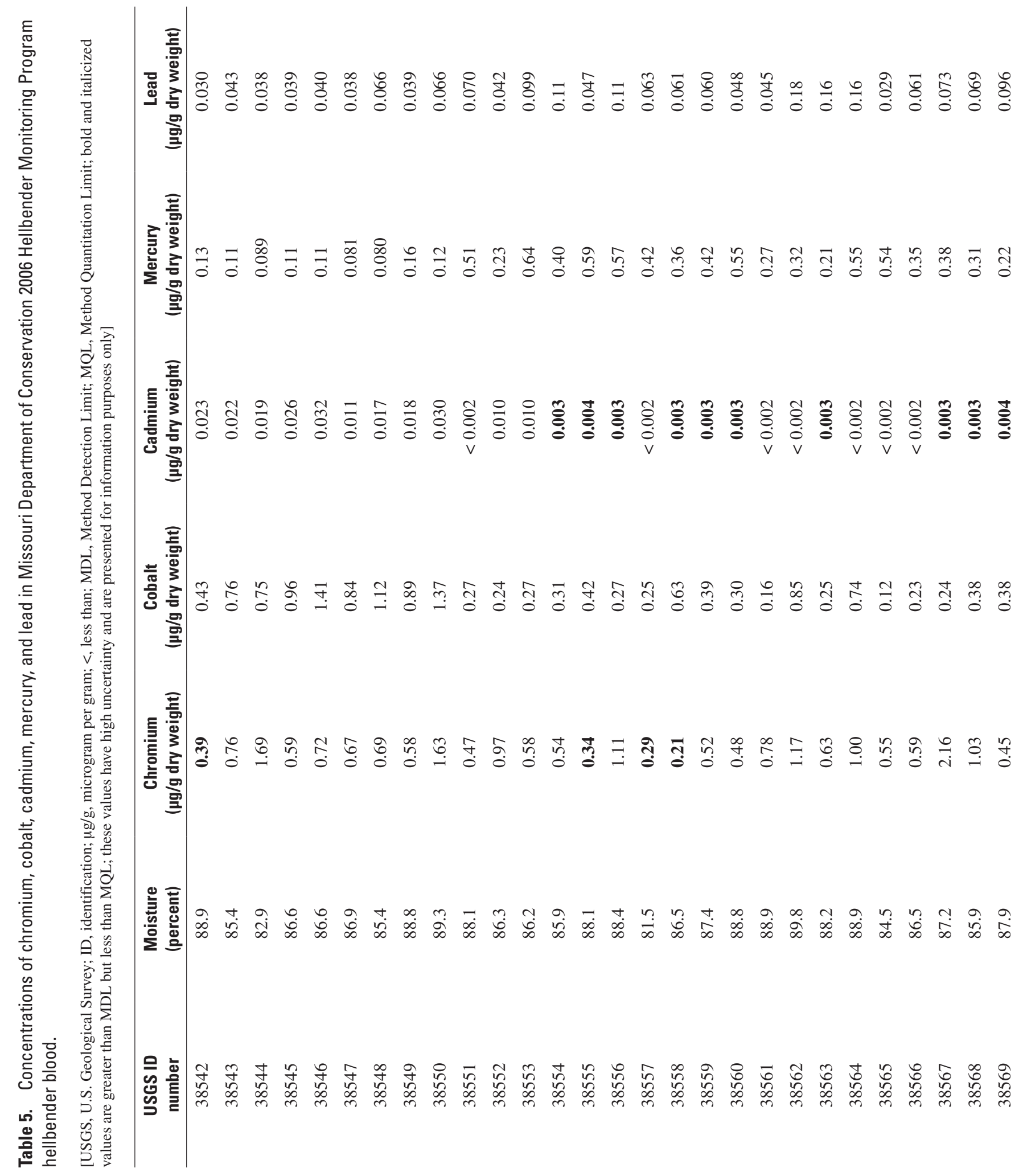




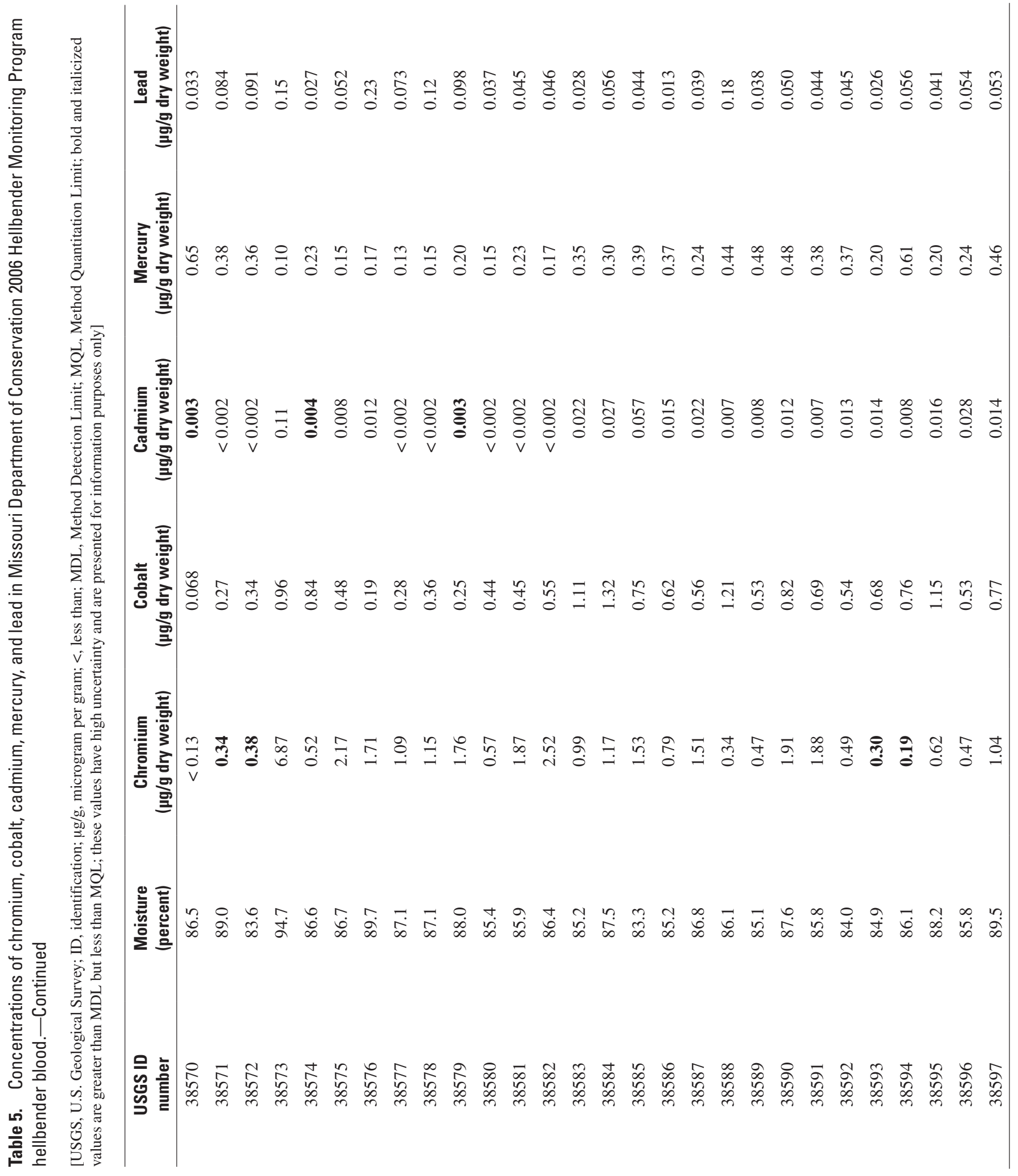



Publishing support provided by:

Rolla Publishing Service Center

For more information concerning this publication, contact: Director, USGS Columbia Environmental Research Center 4200 New Haven Road

Columbia, M0 65201

(573) 875-5399

Or visit the Columbia Environmental Research Center Web site at: http://www.cerc.usgs.gov 

